British \& Irish Botany 2(2): 102-126, 2020

\title{
Increasing status of non-native vascular plants in the Sefton Coast sand-dune system, north Merseyside, UK
}

\author{
Philip H. Smith* \\ Liverpool, UK \\ *Corresponding author: philsmith1941@tiscali.co.uk
}

This pdf constitutes the Version of Record published on $30^{\text {th }}$ June 2020

\begin{abstract}
Over 460 non-native (alien) taxa were recorded in a Sefton Coast sand-dune vascular plant inventory, their proportion in the flora increasing after 1999. Between 2005/06 and 2018, twice as many non-native as native plants were found. An analysis of occurrences of native and non-native taxa in six major habitat types found that a higher proportion of aliens was present in scrub/woodland and disturbed ground, while native plants had more occurrences in fixed dunes/dune grasslands, dune heath and wetlands. No differences between the two groups were detected for strandline/shingle and embryo/mobile dune habitats. Twenty-four non-native and 14 native taxa showed invasive characteristics in the duneland. The former included especially Hippophae rhamnoides and Rosa rugosa, both constituting major threats to sand-dune biodiversity. Particularly invasive native plants were Arrhenatherum elatius, Betula spp., Salix cinerea, and Ulex europaea. The main findings accord with studies elsewhere in Britain and Europe showing recent increases of neophytes in semi-natural habitats and that both non-native and native species can have invasive traits. The open habitats of coastal dunes seem to be particularly susceptible to plant invasions.
\end{abstract}

Key words: alien plants; garden escapes; invasive; Japanese rose; neophytes; sea buckthorn

\section{Introduction}

Non-native (alien) plants have attracted increasing interest in recent decades. Some species are highly invasive, contributing to globally significant environmental problems (Chytry et al., 2008), while most are "common, conspicuous, pestiferous, beautiful, edible and otherwise useful or harmful" (Stace \& Crawley, 2015). The latter authors remarked that alien plants add considerably to a rather limited British flora, contributing 2068 vascular taxa, or $59 \%$ of the total. About 1809 of these were considered neophytes or neonatives, of which $1138(63 \%)$ were naturalised, $342(19 \%)$ casuals and $329(18 \%)$ survivors. Only $57(5 \%)$ were deemed invasive. In addition, at least 2000 plants were beyond the scope of that study, having not been recorded since 1986 or only known as rare casuals. Preston et al. (2002) noted a marked increase in the distribution of neophytes in the British Isles from 1930 to 1999, though their analysis 
probably underestimated the spread, as many species were not mapped in the 1962 Atlas and a "surprisingly large number" had become frequent in Britain.

Crawley et al. (1996) reported a clear declining trend of alien species-richness from Southern England (75\% of the flora) northwards and westwards to northwest Scotland (13\%). Nevertheless, Savidge et al. (1963) considered that the large number of non-native plants recorded in South Lancashire (v.c.59) in the previous 100 years was a "striking feature" of the flora. They cited 635 angiosperm introductions (45\% of the flora) but also noted that only $22(3 \%)$ had become common weeds, recorded from over 50 localities.

A more recent analysis of the non-native flora in Northwest England by Greenwood (1999) found a total of 685 taxa for v.c.59, of which 266 (39\%) were naturalised and $419(61 \%)$ casuals. He also pointed to an increasing proportion of nonnative plants in the recorded flora, from $8 \%$ before 1830 to $44 \%$ between 1930 and 1979 , a rate of addition of between one and two taxa per year. Greenwood suggested that this increase was almost entirely due to human activity, especially escapes from gardens, followed by medicinal and culinary herbs and plants grown in aquaria. Crop escapes were less important, a conclusion also supported by Crawley et al. (1996). Some habitats may be more susceptible to invasion by non-native plants. Thus, Crawley et al. (1996) claimed that British coastal dunes had high numbers of them, especially close to towns, while Stace \& Crawley (2015) described sand-dunes as "a focus for alien plant establishment". Similarly, Chytry et al. (2008) found that the greatest proportion of non-native plants in Catalonia, the Czech Republic and Great Britain occurred in manmade and coastal habitats. Carboni et al. (2010) noted that Italian dunes had a high susceptibility to alien plant invasion, especially near to human settlements containing propagule sources.

The largest sand-dune system in England ( $2100 \mathrm{ha}$ ) is situated on the Sefton Coast, north Merseyside, extending for about $20 \mathrm{~km}$ between the estuaries of the Mersey and Ribble. It supports an exceptionally rich vascular flora (Smith, 2009) which, by 2008, comprised 1143 vascular taxa of which 405 (35.4\%) were introduced (Smith, 2010). The latter suggested that the number of neophytes becoming established in the dunes was increasing and, although most had a low impact, a small number of invasive aliens was causing actual or potential ecological problems. Edmondson (2010a) found that the main sources of non-native plants in this dune system were deliberate plantings of woody species in the past for commercial purposes and dune stabilisation works, dumping of garden waste and propagules washed onto the shore by tides.

An inventory of vascular plants for the Sefton Coast sand-dune system, initially compiled as a draft in 1999, completed in 2005 (Smith, 2006) and updated annually to 2019 , provides an opportunity to examine trends in the numbers and proportion of nonnative taxa, including invasive species, together with their preferred habitats, over a time-scale of 20 years.

\section{Methods}

The Sefton dune system was defined by the extent of blown sand deposits shown on the regional soil-map (Hall \& Folland, 1967). This included most of several golf-courses 
but not built-up areas and some intensively farmed land on the eastern fringes. The study covered all duneland statutorily and non-statutorily designated for its nature conservation interest (Sites of Special Scientific Interest, Special Areas of Conservation and Local Wildlife Sites).

Lists of vascular plants (species subspecies and hybrids), including non-native taxa, reliably identified in the dune system, were compiled from a variety of sources (Smith, 2015). Non-native or introduced native taxa included both archaeophytes and neophytes as defined in Preston et al. (2002). Neophytes and neonatives added since 2005/06 were defined as naturalised, casual or survivor taxa by reference to Stace \& Crawley (2015). A Student's t-test was used to investigate differences between numbers of native and non-native plants found each year.

Occurrences of native and alien plants were ascribed to one or more of ten major habitats: strand-line/shingle, mobile (white) dune, fixed (grey) dune, dune scrub, dune woodland, dune heath, dune wetland, (seasonally flooded slacks, scrapes and ditches) and "disturbed ground", the latter including sites impacted by tipping of garden waste and land damaged or opened up by human trampling, vehicle use, development and agriculture. Chi-square tested the differences between occurrences of native and nonnative taxa in the major habitat types.

Based on personal observations over a period of 50 years, it was possible to identify both native and non-native taxa showing invasive traits in the dune system. Stace \& Crawley's (2015) definition of invasive species was used, namely those that attain a substantial proportion of the biomass of the invaded plant community. Nomenclature followed Stace (2019).

\section{Results}

By 2019, a total of 467 non-native vascular plants had been recorded on the Sefton dunes, $223(48 \%)$ of them being considered naturalised, most of the remainder being casuals. Fig. 1 shows the relationship between number and time since 1999 for natives and non-natives. The trends for both are similar, showing an increase but with a gradual reduction in the rate of addition of new plants. Changes in the proportion of non-native taxa over time are shown in Fig. 2. There was an increase from about $26 \%$ aliens in 1999 to $38 \%$ in 2019, the rate of addition gradually levelling off. 


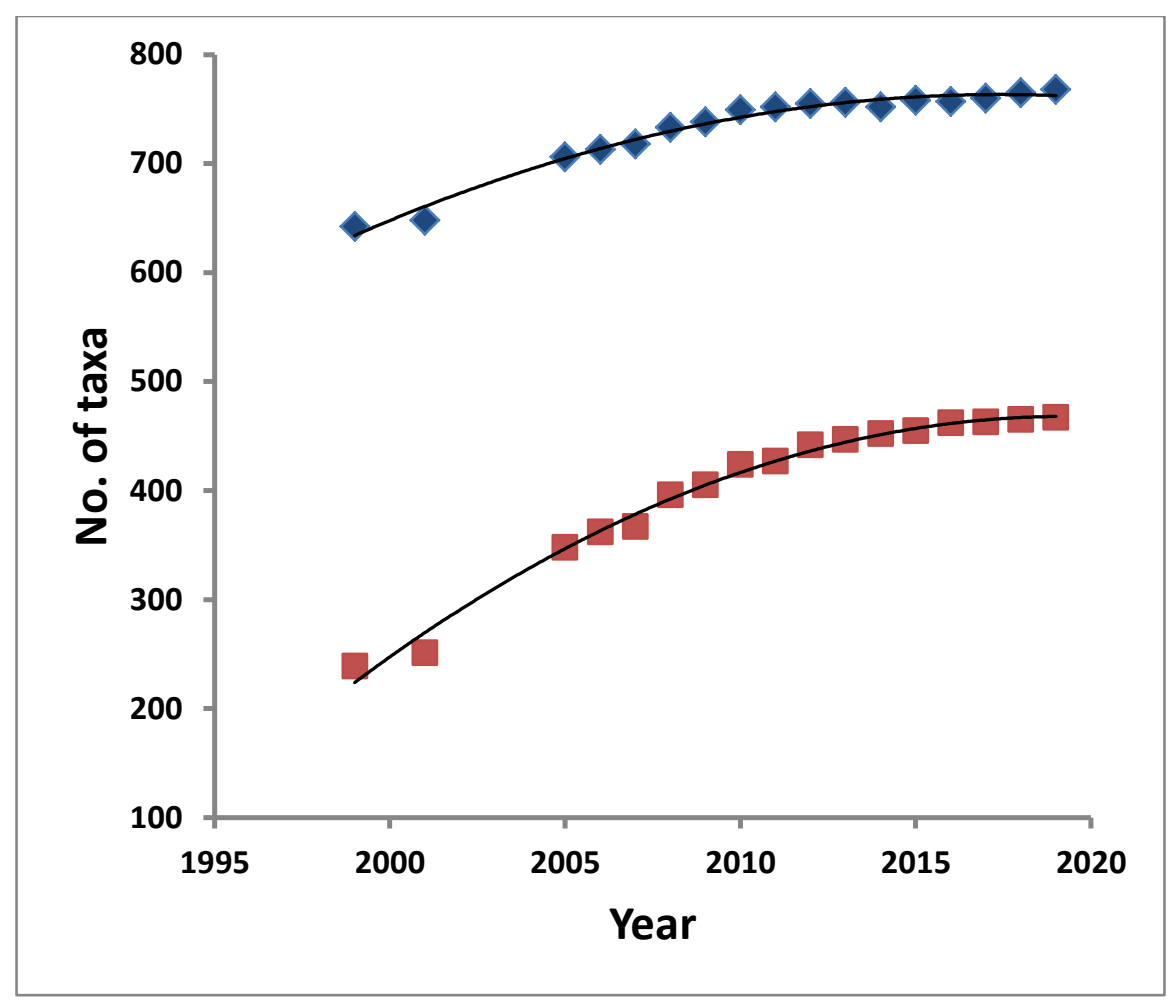

Figure 1. Number of native (blue) and non-native taxa (red) in the vascular plant inventory for the Sefton dune system, 1999-2019.

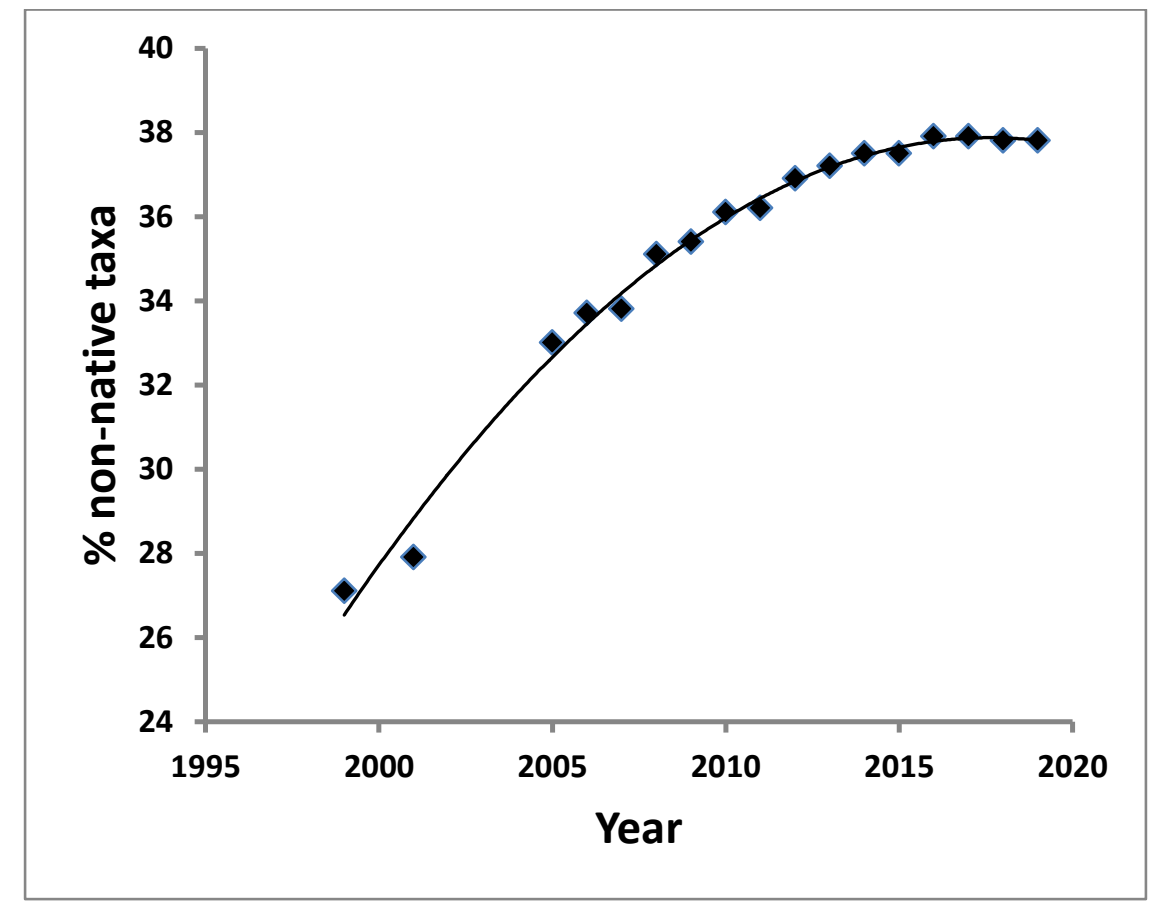

Figure 2. Changes in the proportion of non-native taxa over time in the vascular flora. 
Table 1 shows the numbers of new native and non-native taxa found between 2005/06 and 2018. The annual number ranged from 0 to 6 for natives and 2 to 15 for non-natives, means of 3.2 and 6.3 , respectively, being added per year. There is a significant difference between the means $(t=-2.58 ; p=0.0079)$. Only $10(11.4 \%)$ of the non-natives were naturalised, as defined by Stace \& Crawley (2015), a majority $(47 \%)$ being casuals, while $17 \%$ were survivors. This leaves 21 taxa, 10 of which were listed as archaeophytes. The remaining 11 taxa were not tabulated by Stace \& Crawley (2015), being amongst the 2000 rare casuals or survivors excluded from their work. The rate of addition of new alien plants declined during this period (Fig. 3).

Table 1. Numbers of new native and non-native vascular taxa added to the dune inventory each year from 2005/06 to 2019.

\begin{tabular}{|l|c|c|l|c|c|}
\hline Year & Native & Non-native & Year & Native & Non-native \\
\hline $2005 / 06$ & 6 & 14 & 2013 & 0 & 6 \\
\hline 2007 & 6 & 7 & 2014 & 1 & 2 \\
\hline 2008 & 5 & 9 & 2015 & 4 & 5 \\
\hline 2009 & 4 & 7 & 2016 & 3 & 7 \\
\hline 2010 & 3 & 5 & 2017 & 1 & 3 \\
\hline 2011 & 3 & 3 & 2018 & 3 & 3 \\
\hline 2012 & 3 & 15 & 2019 & 3 & 2 \\
\hline & & & Total & 45 & 88 \\
\hline & & & Mean per annum & 3.2 & 6.3 \\
\hline
\end{tabular}

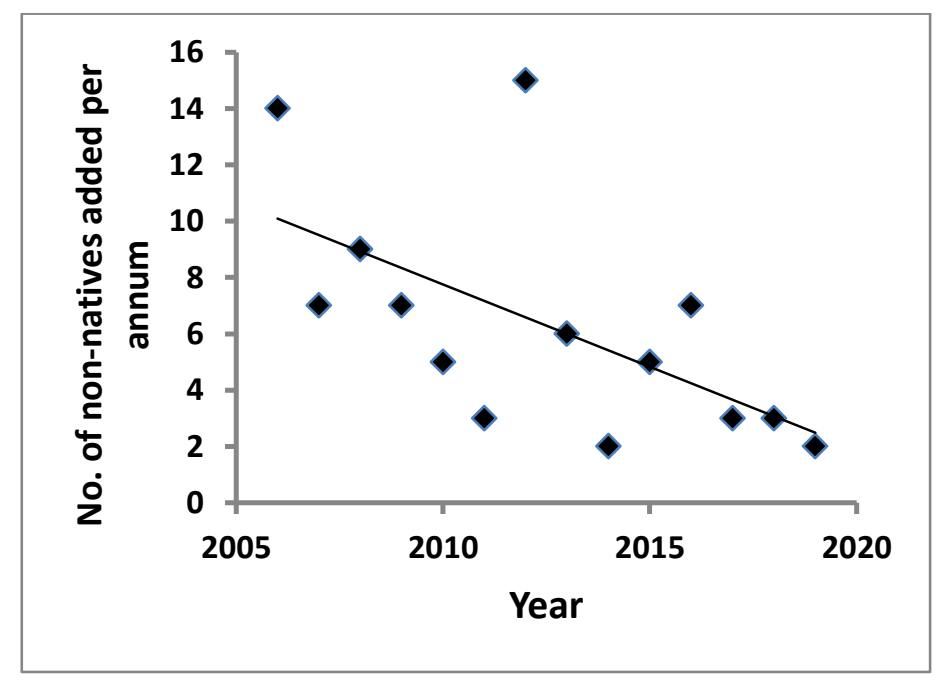

Figure 3. Numbers of non-native plants added per annum $(r=-0.599, p=0.024)$.

An analysis of occurrences of native and non-native taxa in the major habitats is shown in Table 2. Because the observed value for non-native occurrence in embryo 
dunes was less than 5, this habitat was combined with strandline/shingle for Chi-square tests, the results being summarised as follows:

- There was no difference in the occurrences of native and non-native plants in strandline/shingle and in embryo/mobile dune habitats.

- Native plants had higher occurrences than non-natives in fixed dune and dune grassland habitats.

- A higher proportion of aliens than natives occurred in dune scrub and woodland.

- More natives than non-natives were associated with dune heath.

- Dune wetlands had a much lower proportion of non-native than native taxa.

- A much higher proportion of alien than native plants was associated with disturbed ground.

Table 2. Numbers and proportion of native and non-native (alien) vascular plants associated with major habitats in the Sefton Coast sand-dunes. Note that many taxa occur in more than one major habitat type.

\begin{tabular}{|l|c|c|c|c|c|c|c|}
\hline Habitat & $\begin{array}{l}\text { Native } \\
\text { occurrences }\end{array}$ & $\mathbf{\%}$ & $\begin{array}{l}\text { Non-native } \\
\text { occurrences }\end{array}$ & $\mathbf{\%}$ & Total & $\mathbf{X}^{\mathbf{2}}$ & Prob. \\
\hline Strandline/shingle & 20 & 2.1 & 6 & 1 & 26 & 2.4 & 0.12 \\
\hline Embryo dunes & 8 & 0.8 & 1 & 0.2 & 9 & & \\
\hline Mobile (white) dunes & 11 & 1.2 & 15 & 2.6 & 26 & 0.30 & 0.58 \\
\hline Fixed (grey) dunes & 166 & 17.4 & 77 & 13.4 & 242 & 4.57 & 0.03 \\
\hline Dune grassland & 120 & 12.6 & 18 & 3.1 & 138 & 38.7 & $\leq 0.001$ \\
\hline Dune scrub & 64 & 6.7 & 84 & 14.7 & 148 & 25.9 & $\leq 0.001$ \\
\hline Woodland & 71 & 7.3 & 64 & 11.2 & 134 & 5.8 & 0.016 \\
\hline Dune heath & 45 & 4.7 & 7 & 1.2 & 52 & 13.3 & 0.0003 \\
\hline $\begin{array}{l}\text { Dune wetland } \\
\text { (slacks, scrapes and } \\
\text { ditches) }\end{array}$ & 277 & 28.9 & 35 & 6.1 & 310 & 124.4 & $\leq 0.001$ \\
\hline Disturbed ground & 174 & 18.2 & 267 & 46.5 & 440 & 138.9 & $\leq 0.001$ \\
\hline Total & 956 & & 574 & & 1525 & & \\
\hline
\end{tabular}

Table 3 lists the 24 non-native and 14 native plants judged to show invasive characteristics in the Sefton dunes. They represent $5 \%$ of the alien and $2 \%$ of the native flora, respectively. Nine of the invasive non-natives are woody plants, including Pinus spp. (pine) and Populus spp. (poplar), mostly introduced in the $19^{\text {th }}$ century for commercial forestry or sand-fixing purposes. Pine plantations currently cover about 254 ha out of a total of 359 ha of designated woodland on the Sefton Coast (Anon, 2013). Seedlings and young trees of Pinus spp. were found colonising fixed dunes and dune heath (Fig. 4), while Populus alba (white poplar) and P. Xcanescens (grey poplar) have produced extensive areas of secondary woodland since the 1970s, especially on fixed dunes at Birkdale Sandhills Local Nature Reserve (LNR) (Fig. 5). Other non-native treespecies, such as Acer pseudoplatanus (sycamore), Alnus incana (grey alder) and Populus xjackii (balm-of-Gilead) were also found to be important components of these 
mixed secondary woodlands, presently occupying about 105 ha (5\%) of the dune system (Anon, 2013).

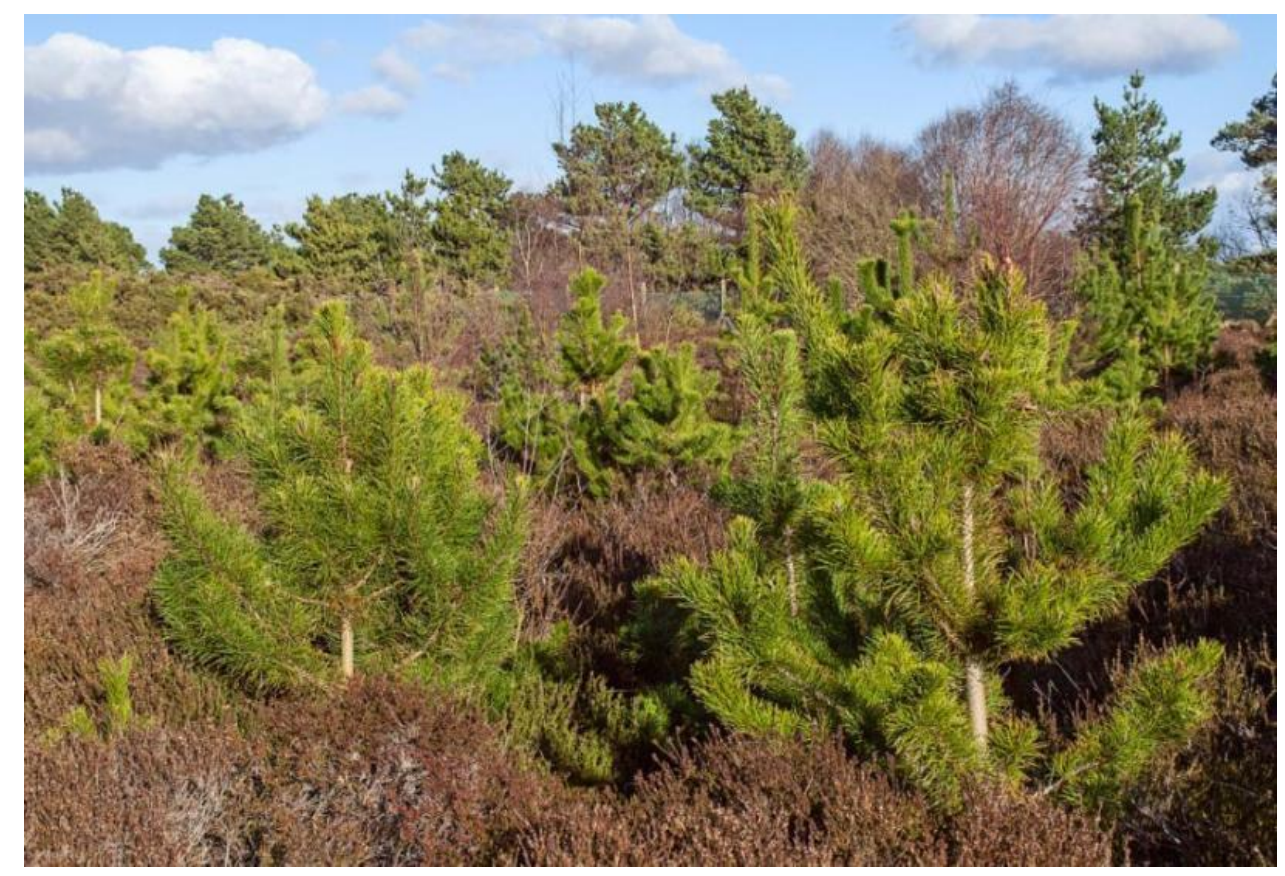

Figure 4. Pinus invasion of dune heath at Freshfield.

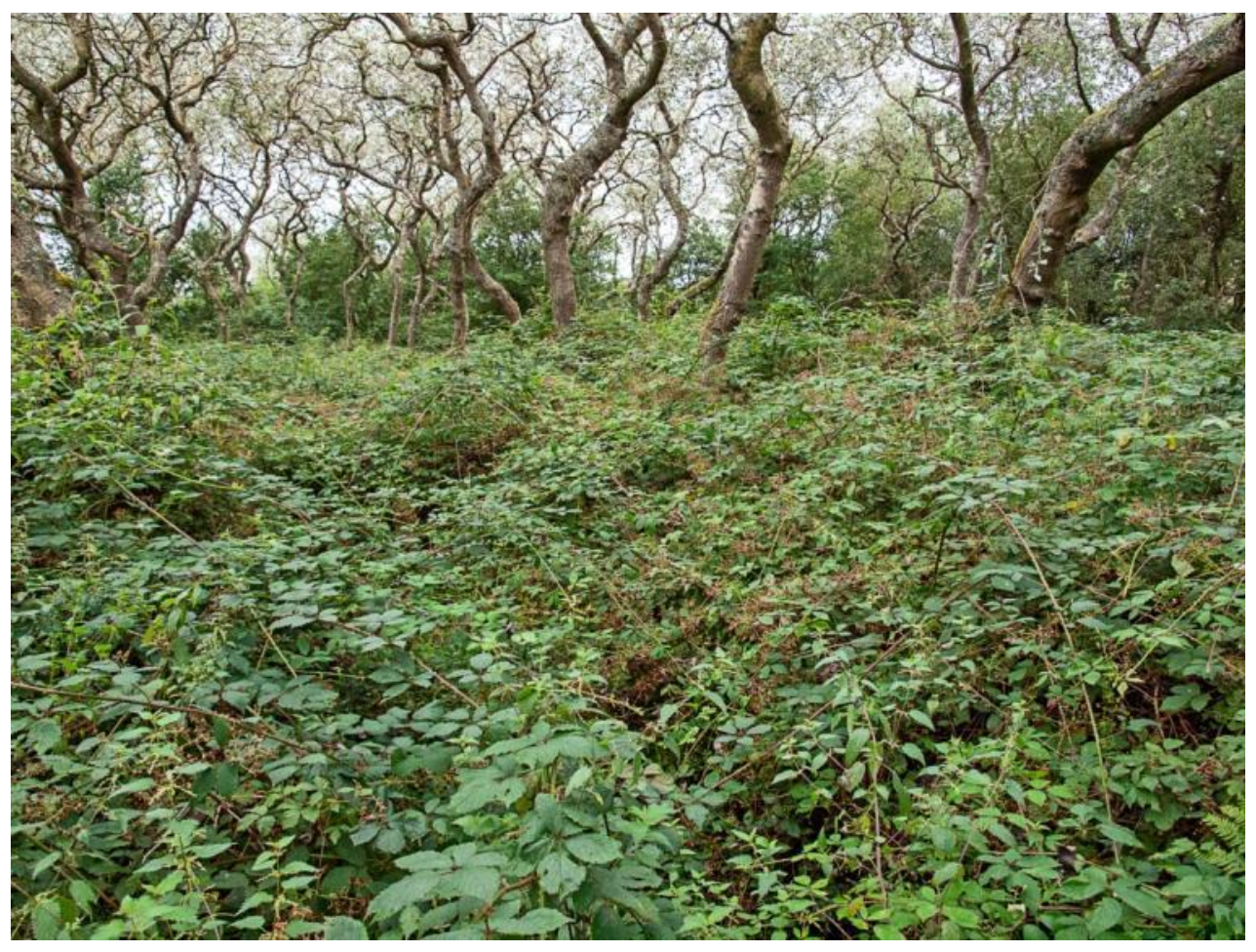

Figure 5. Young secondary woodland of Populus xcanescens with Rubus fruticosus (bramble) understory at Birkdale Sandhills LNR. 
Table 3. Native and non-native vascular plants showing invasive traits in the Sefton Coast dune system ( $A=$ abundant; $L A=$ locally abundant; VLA = very locally abundant; $L D=$ locally dominant; $\mathbf{O}=$ occasional; $\mathbf{R}=$ rare).

Native

\begin{tabular}{|l|l|l|l|}
\hline Taxon & Frequency & Taxon & Frequency \\
\hline Alnus glutinosa & LA & Acer pseudoplatanus & A \\
\hline Arrhenatherum elatius & A & Alnus incana & O \\
\hline Betula pendula & A & Cerastium tomentosum & LA \\
\hline Betula pubescens & LA & Clematis vitalba & LA \\
\hline Calamagrostis epigejos & VLA & Crassula helmsii & R \\
\hline Chamaenerion angustifolium & A & Euphorbia cyparissias & LA \\
\hline Hedera hibernica & LA & Fallopia baldschuanica & O \\
\hline Rubus fruticosus agg. & A & Hippophae rhamnoides & A \\
\hline Phragmites australis & LA & Hyacinthoides xmassartiana & LA \\
\hline Rubus tuberculatus & A & Impatiens glandulifera & VLA \\
\hline Salix cinerea ssp. oleifolia & A & Lathyrus latifolius & LA \\
\hline Salix repens & A & Myriophyllum aquaticum & VLA \\
\hline Typha latifolia & LA & Pinus contorta & LA \\
\hline Ulex europaeus & LA & Pinus nigra ssp. laricio & LD \\
\hline & & Populus xcanescens & LA \\
\hline & & Populus xjackii & A \\
\hline & & Populus alba & A \\
\hline & & Reynoutria $x$ bohemica & O \\
\hline & & Reynoutria japonica & O \\
\hline & & Rosa rugosa & LA \\
\hline & & Sedum album & LA \\
\hline & & Solidago canadensis & LA \\
\hline Total taxa 14 & & Symphyotrichum xsalignus & LA \\
\hline & & Symphyotrichum novi-belgii & LA \\
\hline
\end{tabular}

Native on the east coast of Britain, Hippophae rhamnoides (sea buckthorn) (Fig. 6) was planted here in the 1890 s by the former manorial estates to reduce sand-blow and as a means of excluding trespassers from private duneland (Walmesley-Cotham, 1935). The great reduction in rabbit (Oryctolagus cuniculus) numbers from the late 1950s onwards, due to disease, coincided with this shrub spreading through much of the dune system (Edmondson, 2010a; Smith, 2009). Atkinson \& Houston (1993) quoted an "explosive spread" of $H$. rhamnoides in the slacks of Ainsdale Sand Dunes National Nature Reserve (NNR) in the period from 1960 to 1976. In three of the most invaded areas of duneland, total scrub area increased from 7.7 to 45.3 ha between 1945 and 1985, most of this being $H$. rhamnoides (Smith, 2009). 


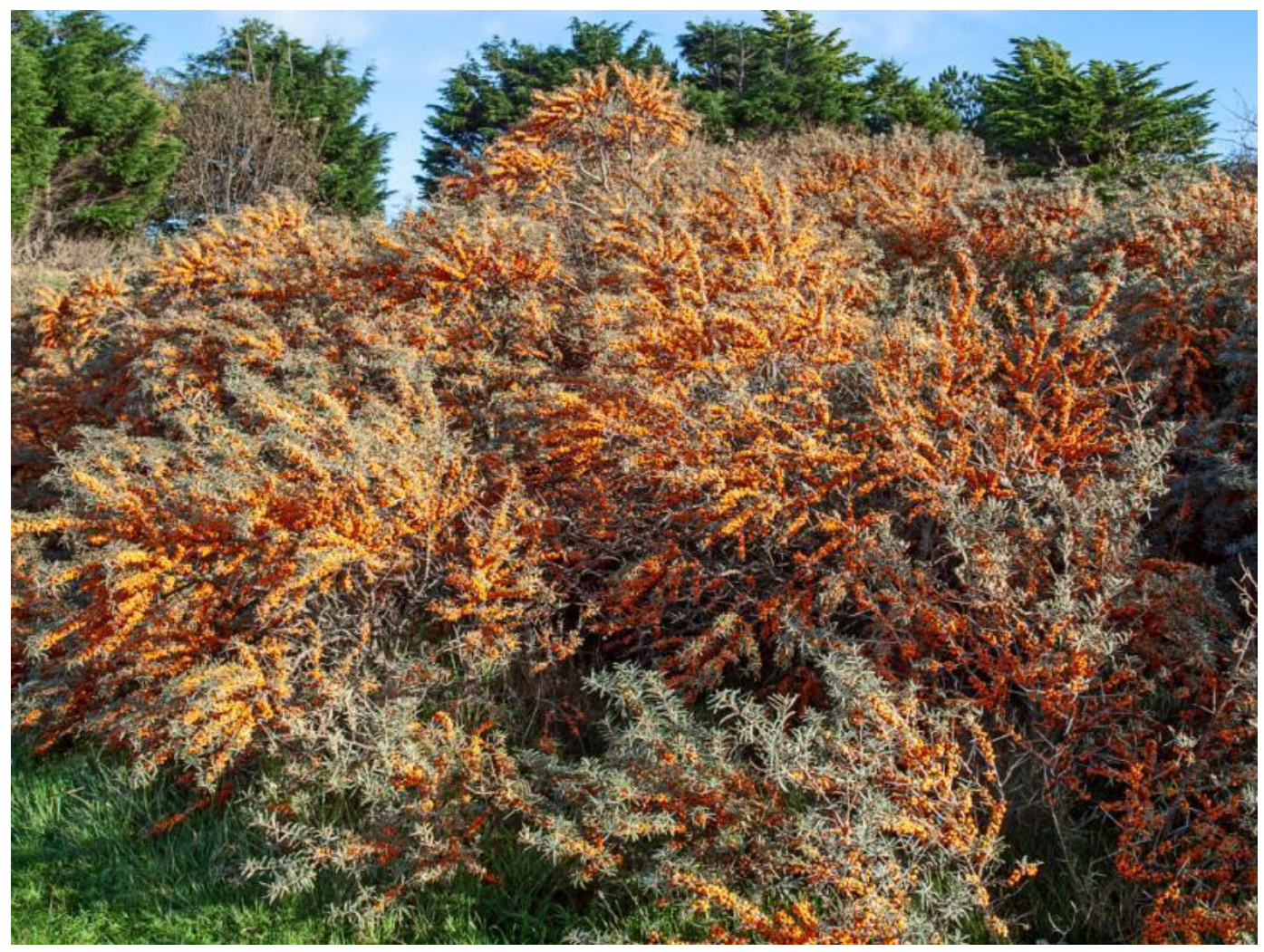

Figure 6. Dense, fruiting Hippophae rhamnoides, Birkdale Common.

With the exception of the aquarists' throw-out, Crassula helmsii (New Zealand pigmyweed), other invasive non-natives are garden-escapes. The most concerning of these is Rosa rugosa (Japanese rose) (Fig. 7), a 2014 survey recording 500 patches on the coast with a total area of nearly 6 ha (Smith \& Deed, 2019). Boardman \& Smith (2016) found that a sample of larger patches was growing in area at a rate of over $20 \%$ per annum, doubling in size every 4-5 years. The perennial herb, Lathyrus latifolius (broad-leaved everlasting-pea) is another potential problem species. First recorded at Waterloo, South Sefton, in about 1900 (Savidge et al., 1963), it was not found during a 1988 UK National Vegetation Classification (NVC) survey of the dune system (Edmondson et al., 1988/89) but was present in four out of 23 units surveyed for the second survey in 2004 (Gateley \& Michell, 2004). Since then, L. latifolius has spread rapidly in mobile and semi-fixed dunes, with records in 20 out of 25 Sefton coastal tetrads in the new flora of South Lancashire database (D.P. Earl, personal communication). During the current study, extensive patches of L. latifolius were found (Fig. 8), especially at Ainsdale and Birkdale LNRs, one covering about 1 ha. Another garden-escape, Symphyotrichum spp. (Michaelmas-daisy), was found to be widespread in the fixed dunes, a patch at Hightown dunes measuring $30 \mathrm{~m}$ in diameter. 


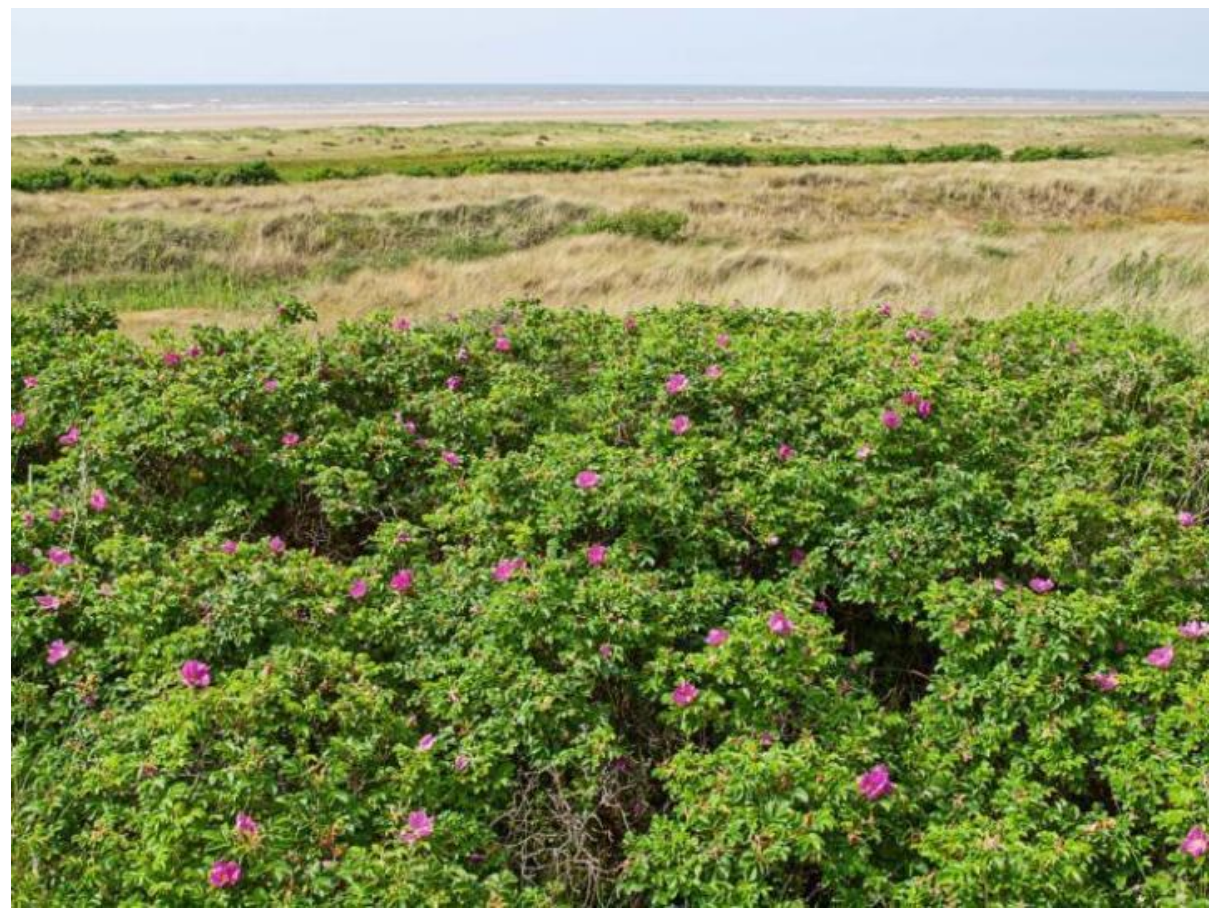

Figure 7. Rosa rugosa, Birkdale frontal dunes.

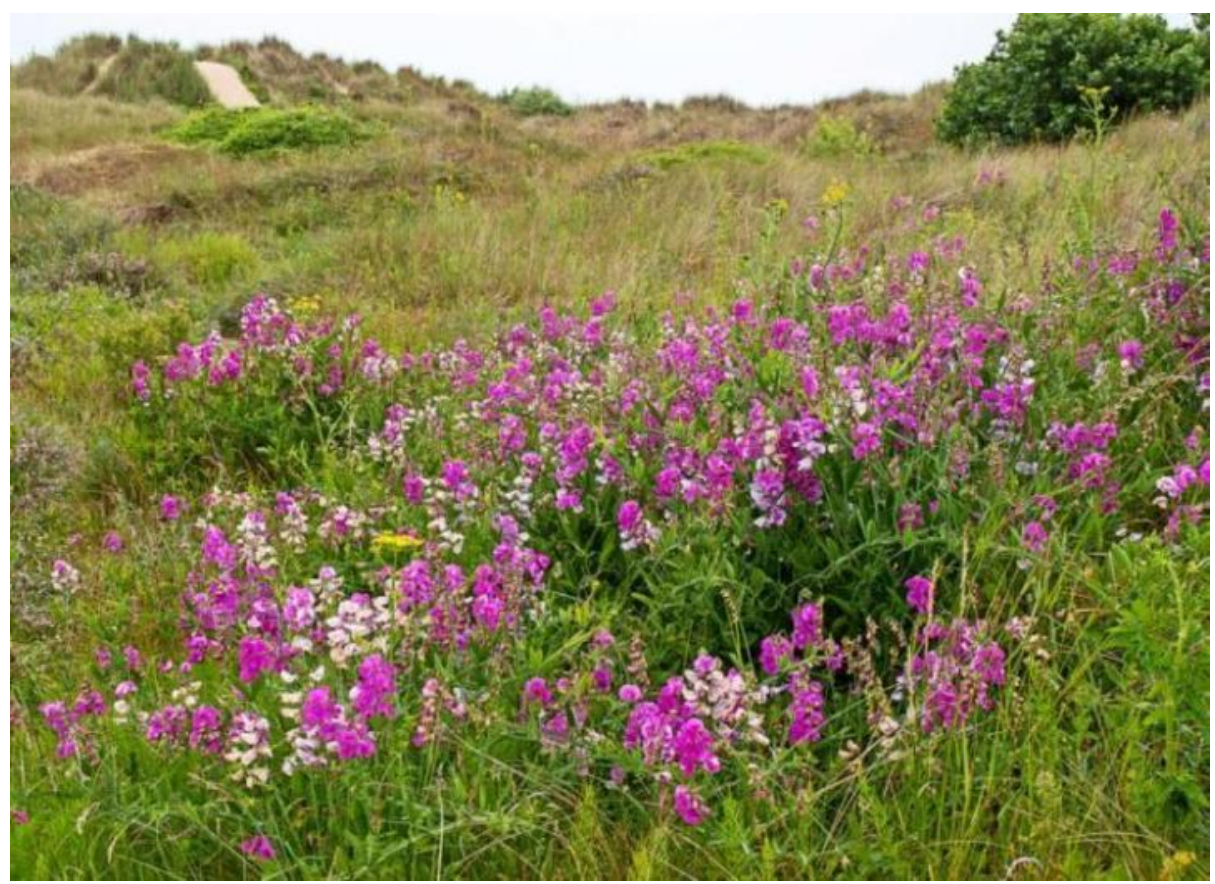

Figure 8. Lathyrus latifolius spreading on the Ainsdale dunes.

Other invasive non-natives were more locally distributed, Cerastium tomentosum (snow-in-summer), Fallopia baldschuanica (Russian vine), Reynoutria spp. (knotweed), Sedum album (white stonecrop) and Solidago canadensis (Canadian goldenrod) forming 
occasional dense, spreading patches, especially in fixed dunes and dune grassland or on the edges of scrub patches, while the extent of Hyacinthoides xmassartiana (hybrid bluebell) increased in areas of dune scrub and secondary broad-leaved woodland. Clematis vitalba (traveller's-joy) is regarded as non-native in South Lancashire (Fitzgerald, 2002; Savidge et al., 1963). It was largely confined to about 10 ha of semifixed and fixed dune habitat north of Shore Road, Ainsdale, where it has been known since 1938 (Savidge et al., 1963). In the last decade, it has increased markedly. Euphorbia cyparissias (cypress spurge) is mainly restricted to Hightown dunes where it has been naturalised for over 40 years (personal observations). Recently, it has begun to spread, being recorded as abundant in about 1 ha of dune grassland (Fig. 9).

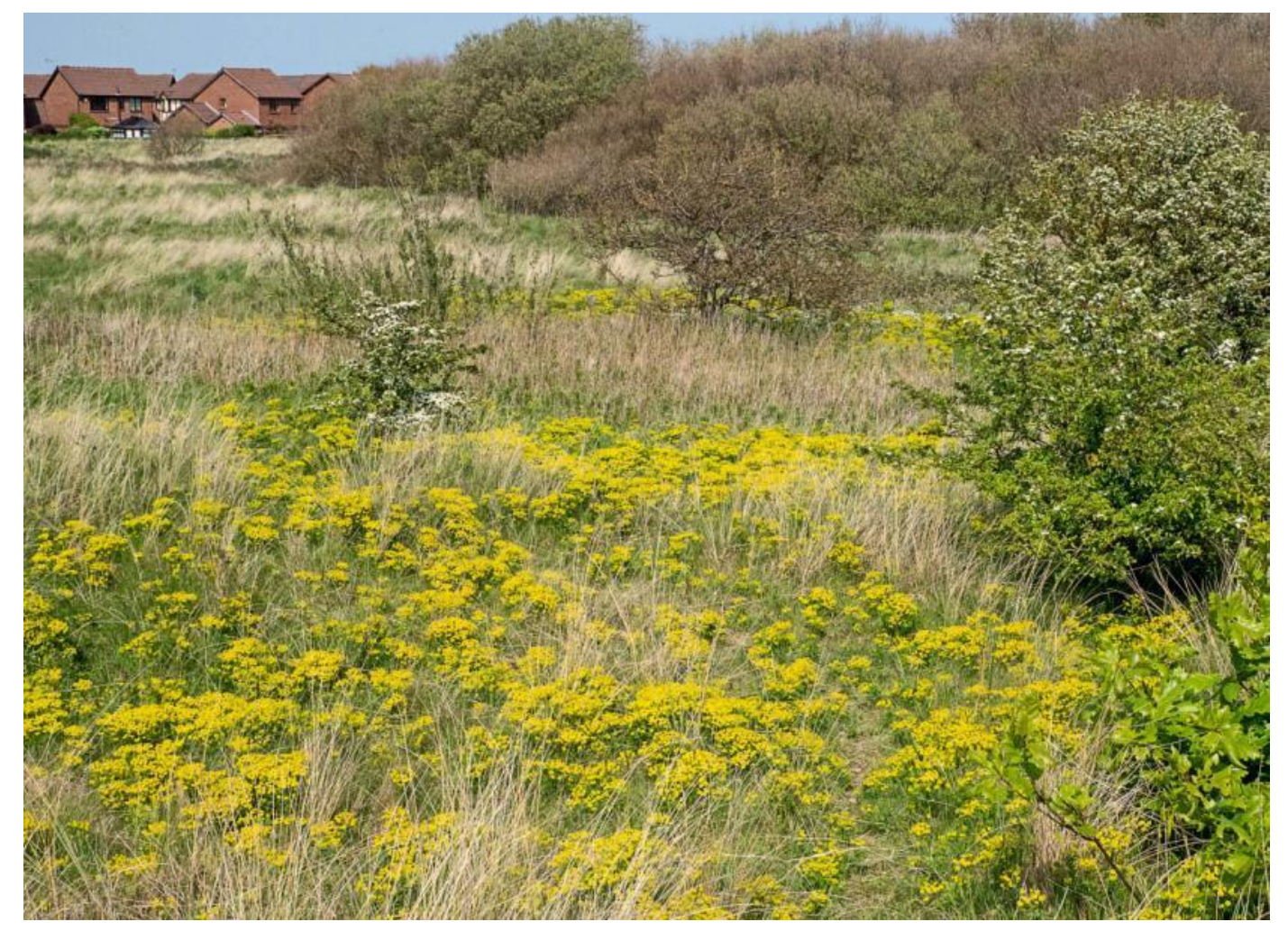

Figure 9. Invasive Euphorbia cyparissias at Hightown dunes.

Of the 14 native taxa considered invasive, five are trees or shrubs. In recent decades, Betula spp. (birch) invaded fixed dunes, dune grasslands and dune heath, especially where pine plantations created shelter from prevailing winds (Fig. 10), as on Ainsdale NNR (Wheeler et al., 1993). Betula and Rubus (bramble) spp. frequently colonised sites where $H$. rhamnoides or pine plantations had been cleared, presumably due to the presence of bare ground for seed germination and enhanced levels of soil nitrogen (Sturgess, 1993). Some wet slacks showed rapid succession to dominant stands of Phragmites australis (common reed) or Typha latifolia (bulrush), or the shrubs, Salix repens (creeping willow), S. cinerea (grey willow) and/or Alnus glutinosa 
(alder), to the disadvantage of competitively inferior, nationally notable specialists such as Juncus balticus (Baltic rush) (Smith \& Lockwood, 2016), Carex viridula (small-fruited yellow-sedge) (Smith, 2017) and Blysmus compressus (flat sedge) (Smith, 2019).

Although localised in the dunes, Calamagrostis epigejos (wood small-reed) formed a dense spreading patch in a small damp-slack near Ainsdale (Smith, 2009). Ulex europaeus (gorse) has spread rapidly on dune heath sites (Fig. 11). NVC studies of the dune system mapped 4.68 ha of W 23: Ulex europaeus - Rubus fruticosus scrub in 1988/89 and 9.02 ha in 2003/04, a 93\% increase in 15 years (Gateley \& Michell, 2004; Edmondson et al., 1988/89).

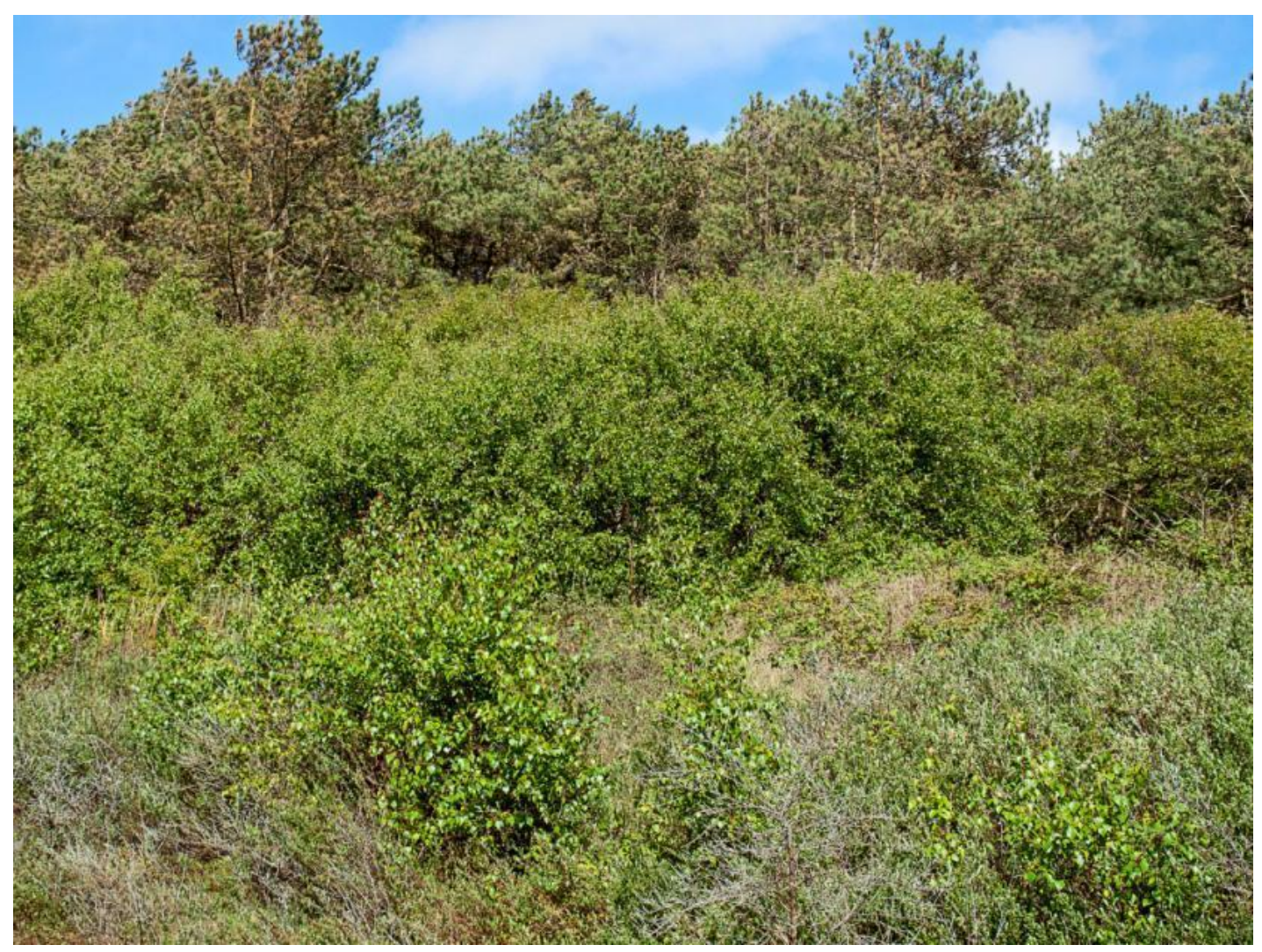

Figure 10. Betula invading duneland in the shelter of pine plantation, Ainsdale NNR.

\section{Discussion}

The number and proportion of non-native vascular plants in the Sefton sand-dunes increased during a 20 -year period, though the rate of addition of new taxa declined. By the end of the study, the 467 alien taxa recorded represented about $38 \%$ of the total flora. This is a substantial increase on previous numbers of non-native plants recorded for the dune system. Thus, Atkinson \& Houston (1993) listed 47 garden-escapes during the $1988 / 89$ NVC survey of the dunes, though they recognised that finding aliens was not a primary aim of the study. By the second NVC survey in 2004, the number of nonnative vascular plants had increased substantially to 194 (Gateley \& Michell, 2004), 
though this was a much smaller total than the 348 recorded the following year for the current study. Between 2005/06 and 2018 an average of six new non-native plants was discovered each year in the dune system. This is a much higher rate than Greenwood's (1999) finding that between one and two alien vascular taxa per annum were added to the flora of South Lancashire over nearly 170 years. These data support the contention that sand-dunes are particularly susceptible to alien plant establishment, perhaps due to the presence of open habitats, high disturbance rates and reduced competition (Chytry et al., 2008; Carboni et al., 2010; Stace \& Crawley, 2015).

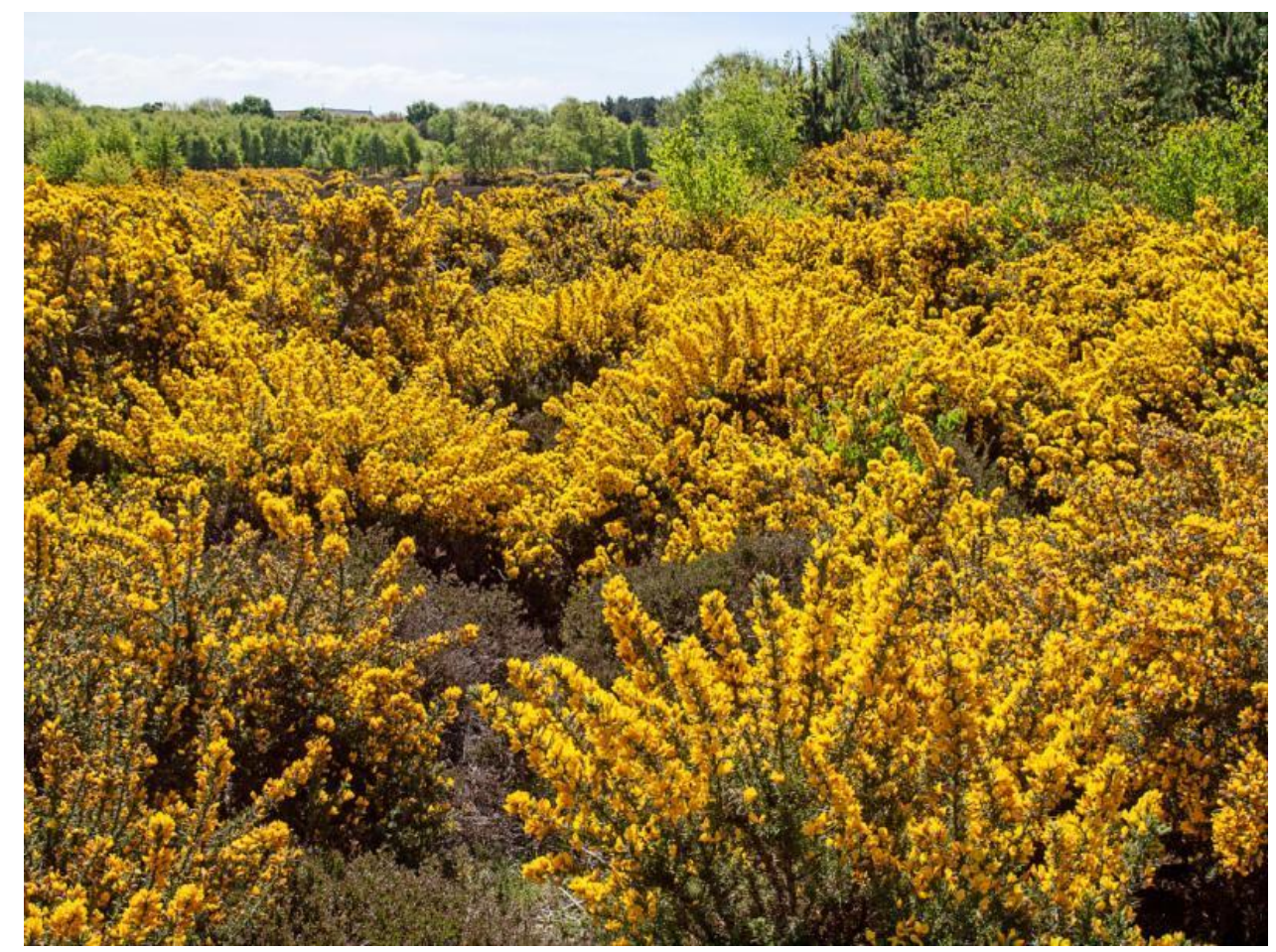

Figure 11. Ulex europaeus colonising Sefton dune heath.

Atkinson \& Houston (1993), Edmondson (2010a) and Smith (2009) highlighted the concentration of non-native plants on the interface between dunes and housing. $A$ study of $8.3 \mathrm{~km}$ of dune-housing boundary in Sefton identified 145 alien taxa with, on average, a garden waste tip every $19 \mathrm{~m}$ and a plant introduction every $12 \mathrm{~m}$ (Edmondson \& Smith, 2005) (Fig. 12).

Savidge et al. (1963) also reported garden refuse near houses as a frequent source of "troublesome" aliens. Smith (2009) found that the proportion of non-native plants on six intensively-studied Sefton dune sites ranged from $13 \%$ to $42 \%$, depending on their proximity to residential development. He also pointed out that not only does garden-waste dumping lead to alien introductions, but it also enriches dune soils, thereby encouraging competitive, nutrient-demanding native species, such as Urtica dioica (common nettle). According to Crawley (1997), most naturalized alien plants usually occur within $10 \mathrm{~m}$ of buildings, gardens, walls, waste ground, roadsides or 
railways, relatively few being seen more than $1 \mathrm{~km}$ from human disturbance. Similarly, Crawley et al. (1996) found that coastal dunes were rich in aliens where they occurred close to towns, as in Southern England and South Wales. The same could equally well apply to Sefton Borough, which is about $50 \%$ built-up, with several large settlements adjoining undeveloped duneland.

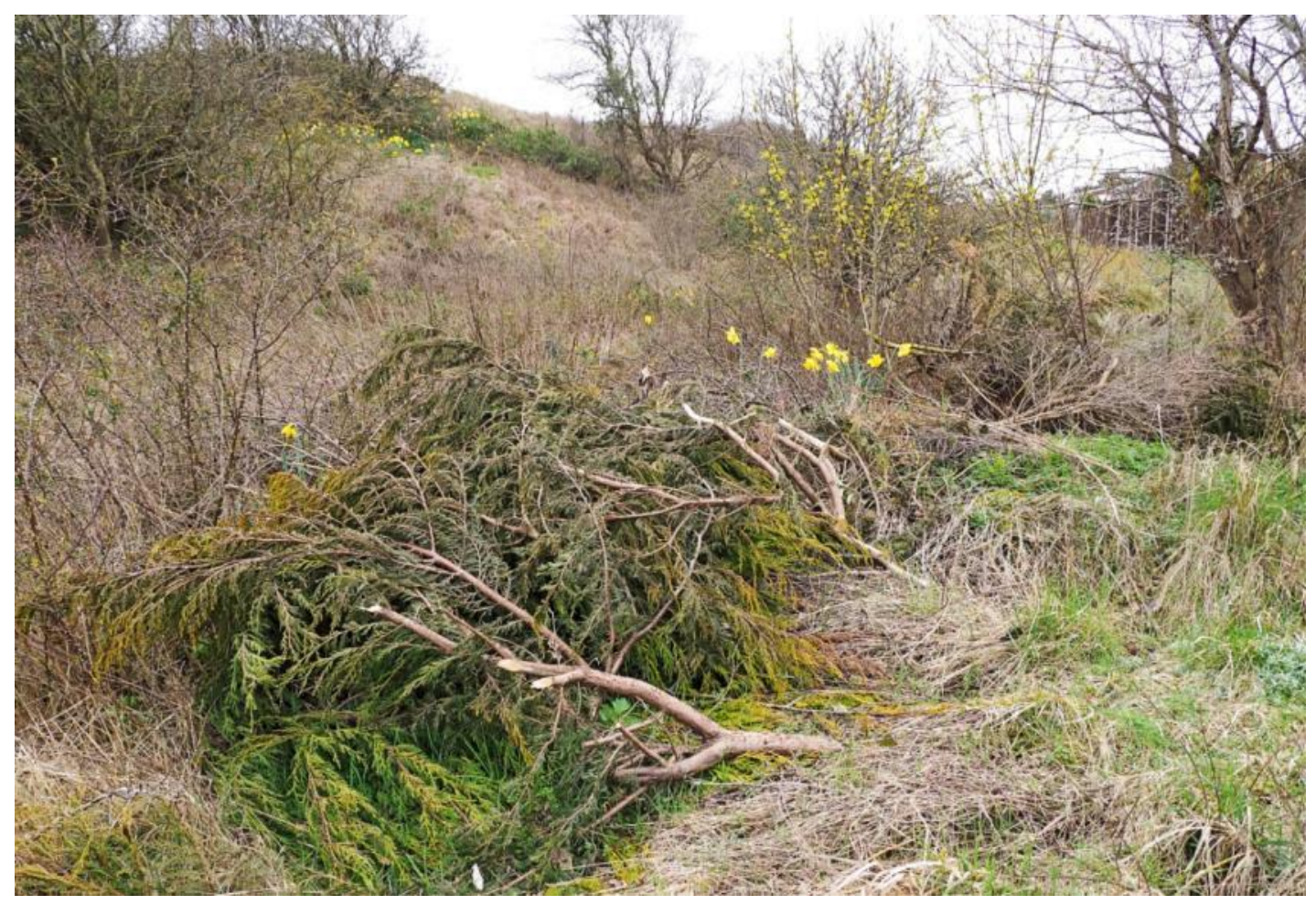

Figure 12. Garden waste tip, Falklands Way dunes, Ainsdale.

This study found no differences in strandline/shingle and embryo/mobile dune preferences for native and non-native taxa. This was unexpected as other studies (e.g. Carboni et al., 2010; Valcheva et al., 2019) detected relatively few alien taxa in early successional stages, suggesting that pioneer dune communities were composed mainly of specialized halophytes and psammophytes adapted to harsh conditions, while neophytes are more usually generalists lacking these adaptations. The small number of both plant groups associated with these habitats may account, in part, for the low occurrences of non-native species.

More native than alien plants were recorded in Sefton fixed dune, dune heath and, especially, dune grassland habitats. Fixed dune and dune heath soils are characterized by low nutrient status, free-drainage, poor water-holding capacity and, in the latter habitat, low pH (Maun, 2009; Millington et al., 2010). Such characteristics may favour adapted native dune and heathland specialists rather than non-native generalists. While the open communities of the fixed dunes may permit colonisation by some hardy non-native plants, the closed swards of dune grassland provide more competitive conditions, perhaps accounting for the lower numbers of aliens recorded. 
Dune scrub and woodland combined supported significantly more non-native than native taxa. This is due to widespread introductions of Pinus and Populus spp. for forestry and other purposes and the many shrubs that have escaped from gardens. Thus, 19 species and hybrids of Cotoneaster (cotoneaster) (Fig. 13), seven Berberis (barberry) and five Spiraea (bridewort) taxa are listed in the coast inventory.

The Sefton dunes are particularly well-endowed with freshwater wetlands, slacks covering at least 115 ha, representing 33\% of the English resource of this habitat (Edmondson, 2010b). The dune wetlands were species-rich but had far more native than alien plants, perhaps due to edaphic conditions. Slack soils are ground-water gleys caused by prolonged seasonal flooding, waterlogging, low oxygen levels and often high sulphide concentrations (Davy et al., 2006). Relatively few non-native plants seem to have evolved adaptations to thrive in such conditions.

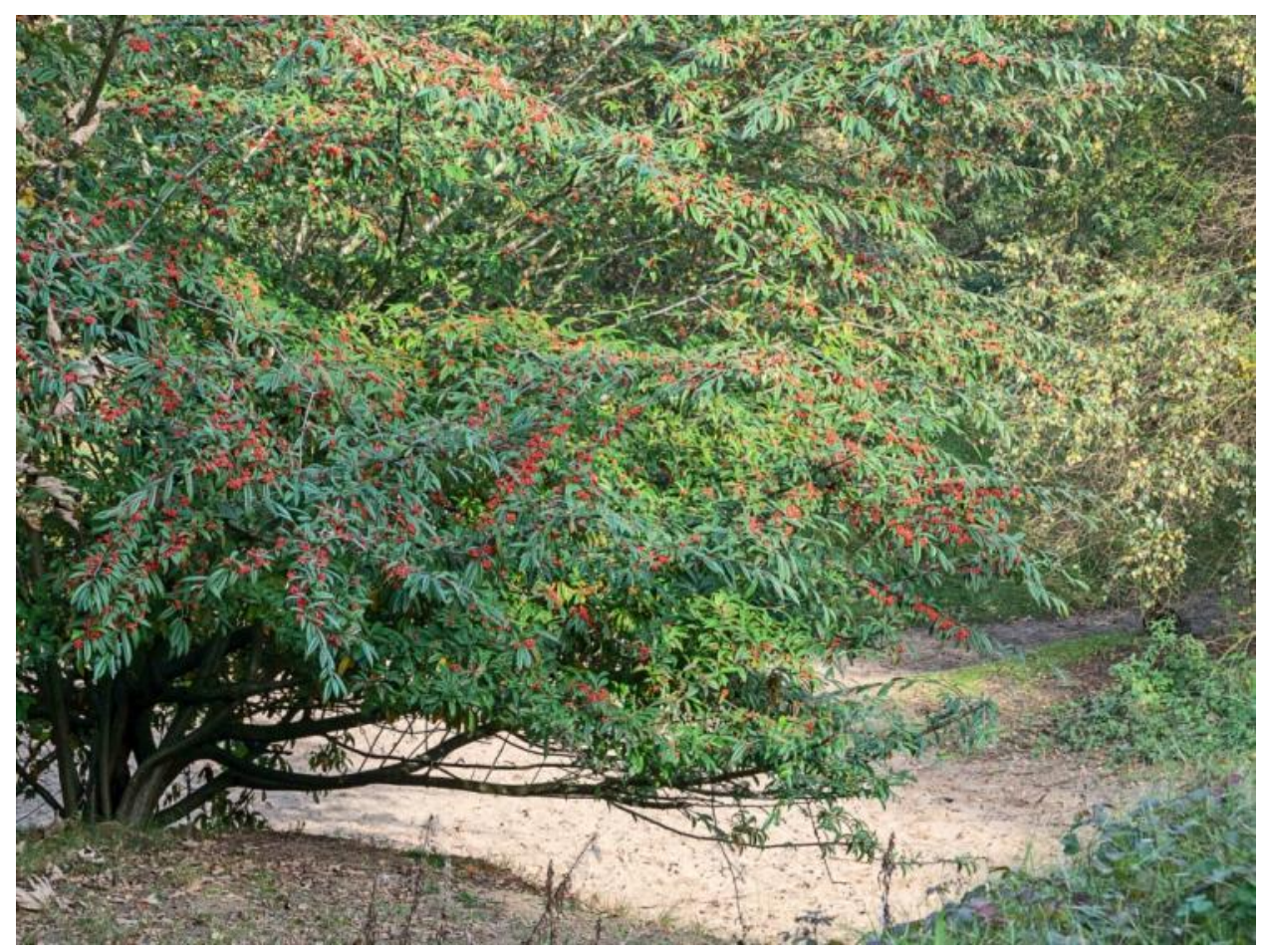

Figure 13. Large bush of Cotoneaster salicifolius at Formby Point.

"Disturbed ground" was shown to support by far the greatest number and proportion of non-native plants. The accords with Crawley et al. (1996) who found that "waste ground" had the highest proportion of aliens in the British flora, while Weeda (2010) reported that most herbaceous neophytes in the Netherlands are characteristic of man-disturbed habitats. Stace \& Crawley (2015) also noted a positive correlation between disturbance and alien plant abundance. They suggested that creation of bare soil would tend to reduce microsite limitations, such as competition from native plants and herbivory, which account for most aliens being relatively uncommon. Most Sefton dune soils are calcareous (Millington et al., 2010), perhaps making these habitats more 
likely to support non-natives, Stace \& Crawley (2015) noting that there are few acidloving aliens.

Only 25 non-native vascular plants ( $5.2 \%$ of aliens, $10.8 \%$ of naturalized aliens and $2 \%$ of the total flora) were considered invasive in the Sefton dune system.

Williamson (1996) proposed a "rule of tens" in which $10 \%$ of invading species become established, while $10 \%$ of those may become pests. On this basis, the number of Sefton Coast aliens showing invasive traits is larger than might have been expected, though several of them remain relatively localised.

Schedule 9 of the Wildlife \& Countryside Act 1981 (as amended) lists species for which it is an offence to "plant or otherwise cause to grow in the wild". Twenty of them are present on the Sefton dunes (Table 4) but, currently, only seven are considered invasive. Five out of the six vascular plants in English Nature's (2005) audit of nonnative species having major adverse environmental effects in England are recorded for the study area (Table 5) but only two of them have invasive traits here. English Nature (2005) also listed 16 non-native plants that were "strongly increasing" (Table 6). Ten were found in the Sefton dunes; the wetland species Crassula helmsii and Myriophyllum aquaticum (parrot's-feather) being the only invasive examples. The latter is restricted to one small pond, while the former has been controlled at most of its few sites by infilling, manual removal and/or use of selective herbicides.

Arguably, the most damaging of the introduced species are Hippophae rhamnoides and Rosa rugosa. These are classic examples of "high impact neophytes" capable of forming dense thickets that exclude most other plants by interspecific competition (Stace \& Crawley, 2015). H. rhamnoides was recognised as a serious threat to duneland biodiversity as long ago as 1969, when the Nature Conservancy established a Hippophae Study Group (Ranwell, 1972). This shrub also adversely impacts coastal dunes in many parts of the Northwest European mainland (Isermann, 2008). In addition to shading out dune flora, $H$. rhamnoides fixes atmospheric nitrogen in root-nodules, thereby enriching the soil, making it less suitable for specialist dune plants, most of which are adapted to oligotrophic conditions (Richards \& Burningham, 2011). Control measures in the Sefton dunes began on a small scale in the late 1960s, increasing in the 1980s and 1990s when heavy machinery was used to clear scrub from large areas (Atkinson \& Houston, 1993). Latterly, funding cuts have meant that volunteers have increasingly been used to control $H$. rhamnoides (Fig. 14), co-ordinated through local conservation charities, land managers and the Gems in the Dunes project.

Rosa rugosa also represents a major threat to dune habitats, both in Britain and elsewhere in Western Europe (Bruun, 2005: Isermann, 2008; Smith \& Deed, 2019; Weeda, 2010). This shrub forms impenetrable thickets, eliminating most other plants by shading, as well as hindering access (Isermann, 2008). Stefanowicz et al. (2019) showed that $R$. rugosa invasion of sand dunes increases soil organic carbon, total nitrogen and phosphate, while the organic matter layer under the shrub is thicker, with higher $\mathrm{pH}$ and calcium. Reduced microbial activity is possibly linked to production of secondary metabolites, high phenolic concentrations being found in senescing $R$. rugosa leaves. These findings show that $R$. rugosa alters the nutrient status of dune soils and may hinder recovery of habitats after removal of the plant. Despite known impacts 
nationally and internationally and its inclusion in Schedule 9 of the Wildlife \& Countryside Act, $R$. rugosa is still widely advertised, recommended on television gardening programmes and sold in garden centres. Weeda (2010) recommended that alien woody plants including $R$. rugosa should not be planted in or near to sand-dunes.

Table 4. Wildlife \& Countryside Act Schedule 9 vascular taxa present on the Sefton Coast dunes (* considered invasive in the Sefton dune system).

\begin{tabular}{|l|l|l|}
\hline Taxon & English name & $\begin{array}{l}\text { Status on the } \\
\text { Sefton Coast }\end{array}$ \\
\hline Azolla filiculoides & water fern & Rare \\
\hline Cotoneaster bullatus & hollyberry cotoneaster & Occasional \\
\hline Cotoneaster horizontalis & wall cotoneaster & Rare \\
\hline Cotoneaster simonsii & Himalayan cotoneaster & Occasional \\
\hline Crassula helmsii* & New Zealand pigmy-weed & Rare \\
\hline Crocosmia xcrocosmiiflora & montbretia & Occasional \\
\hline Elodea canadensis & Canadian waterweed & Occasional \\
\hline Elodea nuttallii & Nuttall's waterweed & Rare \\
\hline Heracleum mantegazzianum & giant hogweed & Occasional \\
\hline Impatiens glandulifera* & Himalayan balsam & Occasional \\
\hline Lagarosiphon major & curly pondweed & Occasional \\
\hline Lamiastrum galeobdolon ssp. argentatum & yellow archangel & Occasional \\
\hline Myriophyllum aquaticum* & parrot's-feather & Rare \\
\hline Parthenocissus quinquefolia & Virginia-creeper & Rare \\
\hline Reynoutria xbohemica* & Bohemian knotweed & Occasional \\
\hline Reynoutria japonica* & Japanese knotweed & Occasional \\
\hline Reynoutria sachalinensis* & giant knotweed & Rare \\
\hline Rhododendron ponticum & rhododendron & Occasional \\
\hline Robinia pseudoacacia & false-acacia & Rare \\
\hline Rosa rugosa* & Japanese rose & Frequent \\
\hline
\end{tabular}

Table 5. Vascular taxa in English Nature's (2005) audit of non-native species in England having major adverse environmental effects $(*=$ present in the Sefton dunes).

\begin{tabular}{|l|l|l|}
\hline Taxon & English name & Status on Sefton dunes \\
\hline Acer pseudoplatanus* & sycamore & Abundant; invasive \\
\hline Carpobrotus edulis & hottentot-fig & Absent \\
\hline Heracleum mantegazzianum* & giant hogweed & Occasional \\
\hline Quercus ilex* & evergreen oak & Rare \\
\hline Reynoutria japonica* & Japanese knotweed & Occasional; invasive \\
\hline Rhododendron ponticum* & rhododendron & Occasional \\
\hline
\end{tabular}


Table 6. Strongly increasing non-native vascular plants in English Nature's (2005) audit of non-native species in England (* = present in the Sefton dunes).

\begin{tabular}{|l|l|l|}
\hline Taxon & English name & $\begin{array}{l}\text { Status in Sefton } \\
\text { dunes }\end{array}$ \\
\hline Amsinckia micrantha* & common fiddleneck & Rare \\
\hline Brassica napus* & oil-seed rape & \\
\hline Buddleja davidii* & butterfly-bush & Occasional \\
\hline Conyza sumatrensis* & Guernsey fleabane & Occasional \\
\hline Cotoneaster integrifolius & entire-leaved cotoneaster & \\
\hline Cotoneaster microphyllus agg. & small-leaved cotoneaster & \\
\hline Crassula helmsii* & New Zealand pigmyweed & Rare; invasive \\
\hline Hirschfeldia incana* & hoary mustard & Occasional \\
\hline Hydrocotyle ranunculoides & floating pennywort & \\
\hline $\begin{array}{l}\text { Lamiastrum galeobdolon ssp. } \\
\text { argentatum* }\end{array}$ & yellow archangel & Occasional \\
\hline Lemna minuta & least duckweed & \\
\hline Leucanthemum xsuperbum* & shasta daisy & Occasional \\
\hline Linum usitatissimum* & flax & Rare \\
\hline Myriophyllum aquaticum* & parrot's-feather & Rare \\
\hline Polypodon viridis & water-bent & \\
\hline Valerianella carinata & keeled-fruited cornsalad & \\
\hline
\end{tabular}

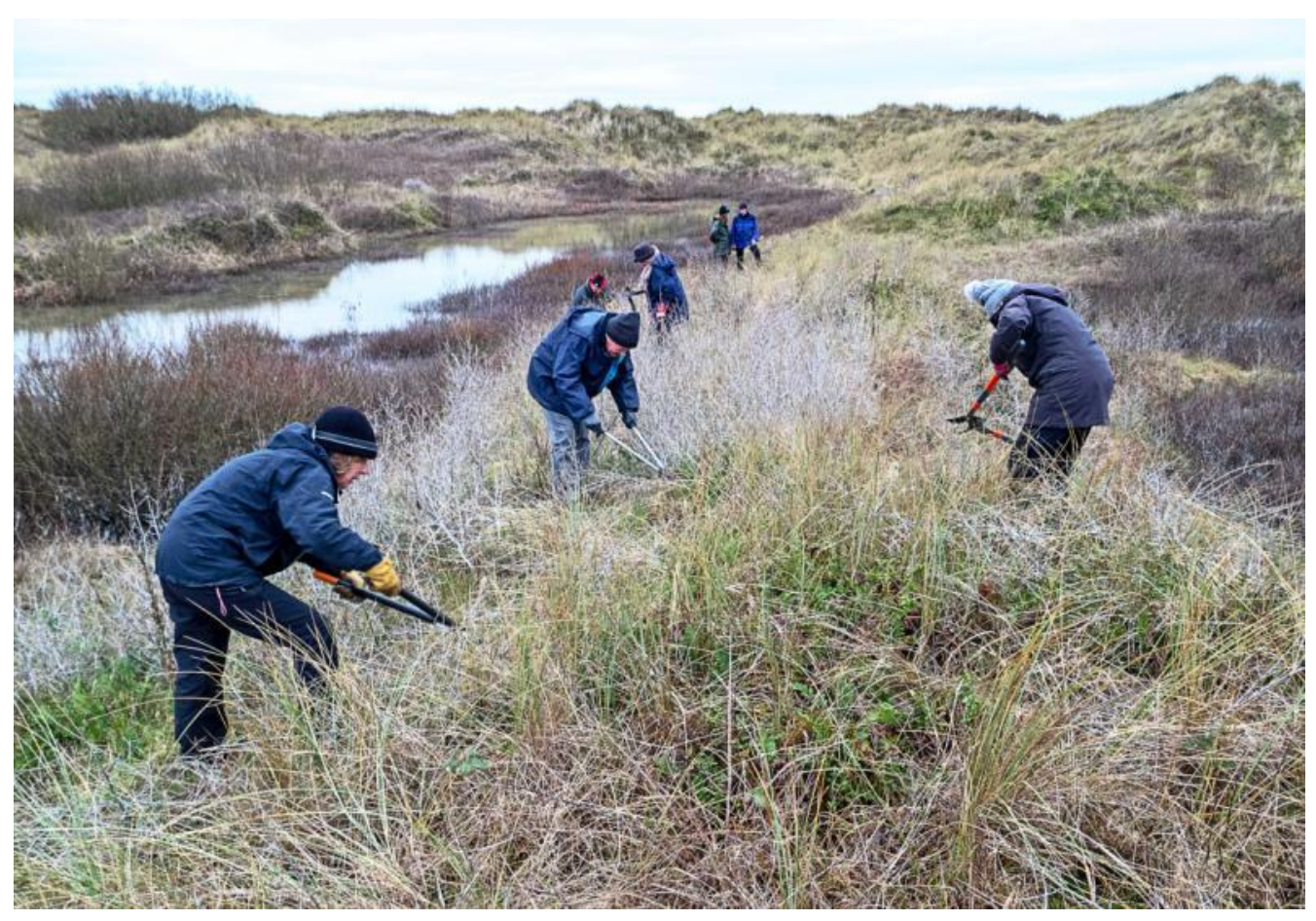

Figure 14. Control of Hippophae rhamnoides by volunteers at Birkdale dunes. 
Large-scale control of $R$. rugosa on the Sefton dunes began in 2017 with mechanical excavation and deep burial of bushes at Cabin Hill NNR and Altcar Training Camp (Fig. 15), supported by Gems in the Dunes, the Defence Infrastructure Organisation and Natural England. The Dynamic Dunescapes project proposes to extend this work to other parts of the dune system. Fortunately, the Sefton dunes are not threatened, as yet, by some woody invasives, such as Prunus serotina (rum cherry) and Yucca spp. (yucca), that have damaged the ecology of dune systems elsewhere in Europe. Weeda (2010) referred to the "huge and unforeseen problems" caused by $P$. serotina which was introduced to the Netherlands from North America. Only three bushes of this species have been found on the Sefton Coast and these show little sign of spreading. Similarly Yucca spp. are rare here, a small group of individuals having been removed during recent works to control Rosa rugosa on Altcar Training Camp dunes.

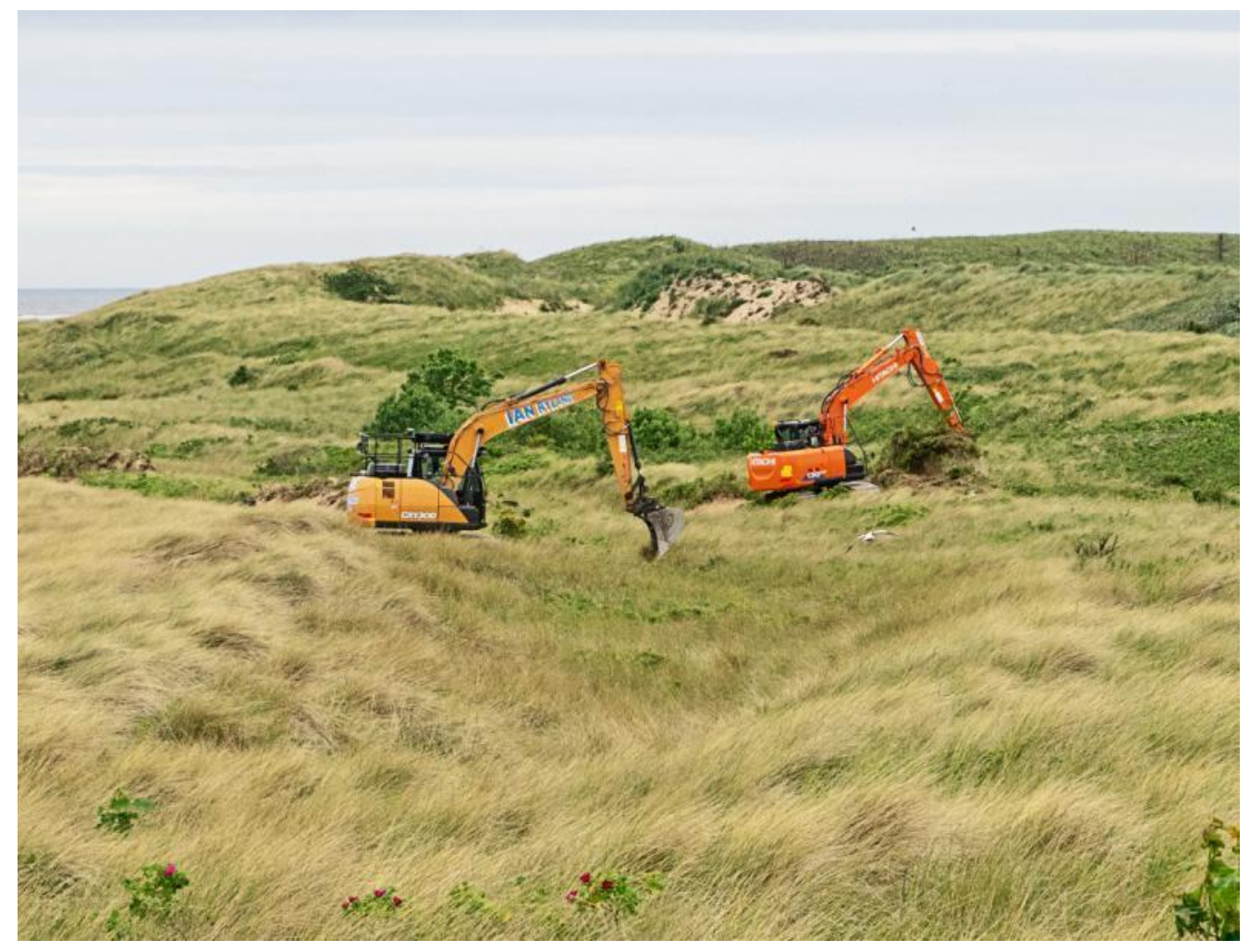

Figure 15. Mechanical removal of Rosa rugosa at Altcar Training Camp frontal dunes.

Another invasive non-native plant, Cerastium tomentosum, is problematic on duneland elsewhere in the UK, producing white carpets over hundreds of square metres in the North Norfolk dunes (Stace \& Crawley, 2015). Houston (2011) reported the vigorous growth of Clematis vitalba at Gibraltar Point NNR and SaltfleetbyTheddlethorpe NNR in Lincolnshire, where it was described as invasive. Pearman et al. (2019) listed this species as one of ten most invasive "natives" in Cornwall, where it is becoming dominant in hedgerows and dune systems. Fitzgerald (2002) observed that $C$. 
vitalba can form "virtual monocultures" on base-rich soils, while Pearman (2007) reported that Euphorbia cyparissias was increasing nationally on light soils. A literature search did not find any examples of Lathyrus latifolius as an invasive plant on sanddunes, though Breeds (2004) mentioned that it was established in at least three places on Braunton Burrows, Devon.

Fourteen native plants were identified as being invasive in the Sefton dune system (Table 3), five being woody species. Scrub invasion by both non-native and native plants has been recognised as a major issue on the Sefton dunes for several decades (Smith, 2009). Wheeler et al. (1993) described rapid succession on fixed dunes towards dune scrub and woodland of limited nature conservation value, birch being widespread and increasing in abundance. They attributed this, in part, to a reduction in grazing pressure following a decline of the Rabbit population. Rodwell (2000) also highlighted birch invasion of dune grassland communities following the removal or demise of grazers.

Colonisation of dune slacks by bushy Salix spp. and Betula pendula (silver birch) was cited by Rodwell (2000) as a precursor to woodland. Smith \& Kimpton (2008) described the effect of removing 1 ha of dense Salix cinerea from a slack at Cabin Hill NNR where most of the previously rich flora had been shaded out (Fig. 16). After clearance, the site was colonised by 139 vascular taxa over two years. However, the authors also highlighted the spread of mono-specific stands of Phragmites australis and Phalaris arundinacea (reed canary-grass) in the slack, with concerns for future biodiversity. Smith (2019) also reported the growth of larger Salix taxa as a potential threat to the Red List "Vulnerable" Blysmus compressus, recommending targeted scrub control in Sefton dune slacks supporting this species.

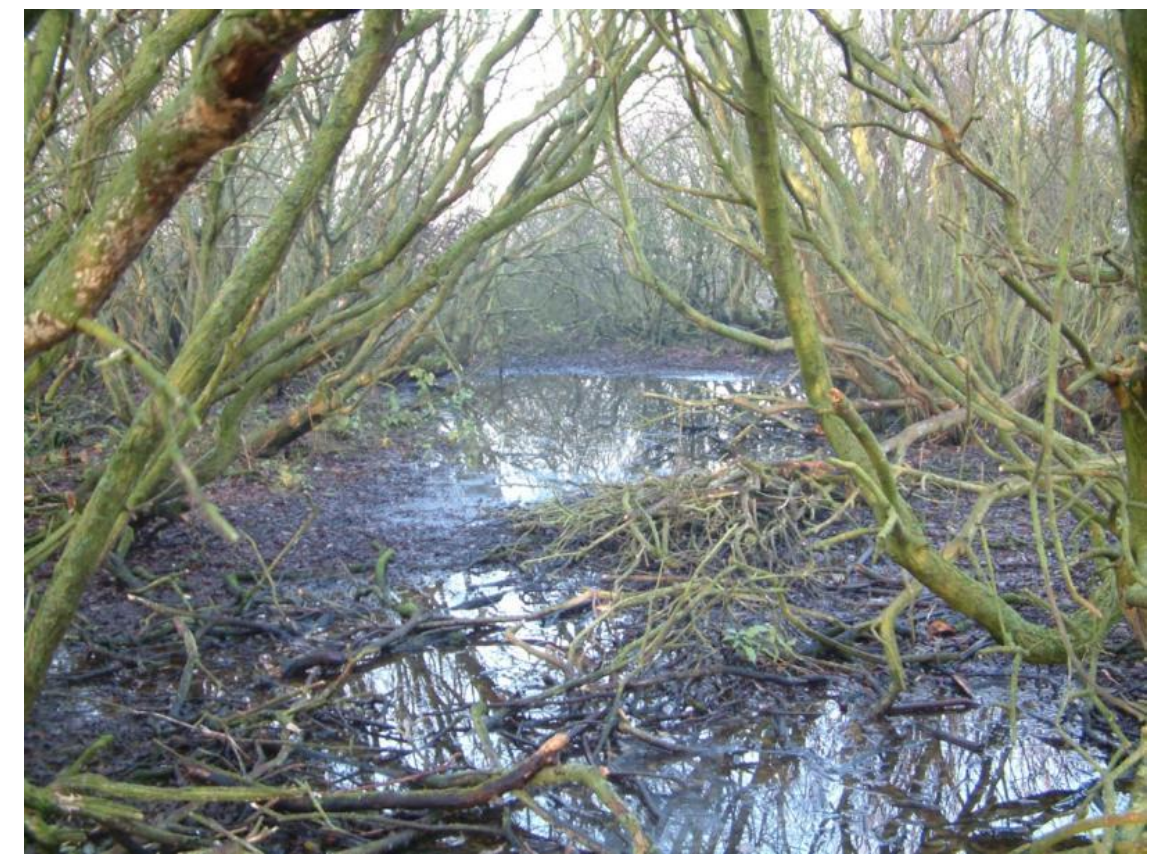

Figure 16. Dense Salix cinerea in a Cabin Hill NNR slack before clearance in 2005. 
An increase from 11 ha in 1988/89 to nearly 160 ha in 2003/04 of mesotrophic grassland containing much Arrhenatherum elatius (false oat-grass) was reported on the Sefton Coast by Gateley \& Michell (2004). During the same period, the NVC's SD9: Ammophila arenaria-Arrhenatherum elatius dune grassland community doubled in extent. This rank, tussocky, species-poor community extended seawards into previously open mobile-dune habitat. The development of coarse grassland on dunes has been widely reported elsewhere in Britain and Western Europe (Houston, 2008), being attributed not only to reduced grazing pressure but also to aerial deposition of nitrogen (Jones et al., 2004) which exacerbates soil eutrophication.

The impact of invasive native species is widely acknowledged. Marrs et al. (2013) argued that a few aggressive native plants may have an equal or greater impact on some habitats than alien species, while Pearman (2004) contended that a small number of native plants was a greater threat to the UK's native flora than invasive non-natives. Pearman \& Walker (2009) and Pearman et al. (2019) added to this debate, stressing that the great majority of naturalised alien plants are benign, most being restricted to highly modified environments near to urban centres. Analysis of tetrad distributions suggested that naturalised non-natives are "vanishingly rare" in closed semi-natural communities of high conservation value and that aggressive native species represent a much greater threat to our flora. However, Rand (2009) criticised Pearman \& Walker's data analysis, pointing out that it did not address impacts on individual sites.

The current study demonstrates that a large sand-dune system is susceptible to invasion by both non-native and native plants, with introductions such as Hippophae rhamnoides and Rosa rugosa being especially problematic. However, native colonists including Arrhenatherum elatius, Betula spp., Salix spp. and Ulex europaea, can produce ecological impacts of a similar magnitude. A quantitative assessment of the distribution, population size and growth rate of invasive species on the Sefton dunes has only been carried out for $R$. rugosa (Boardman \& Smith, 2016; Smith \& Deed, 2019). Similar studies for taxa, such as $H$. rhamnoides, L. latifolius, Betula spp. and Salix spp. are urgently required so that strategies for their effective control can be formulated and enacted.

\section{Acknowledgements}

I am grateful to many botanists who contributed records or otherwise assisted this study, in particular S.E. Edmondson, D.P. Earl, P.S. Gateley, P.A. Lockwood, B.A. Tregale and M.P. Wilcox. Richard Burkmar kindly provided statistical advice.

\section{References}

Anon. 2013. The Sefton Coast woodlands phase II overview: a 20-year working plan, 2013-2032. Warrington: The Mersey Forest.

Atkinson, D. \& Houston, J., eds. 1993. The sand dunes of the Sefton Coast. Liverpool: National Museums \& Galleries on Merseyside.

Boardman, C. \& Smith, P.H. 2016. Rates of spread of Rosa rugosa (Japanese Rose) determined by GIS on a coastal sand-dune system in Northwest England. Journal of Coastal Conservation 20: 281-287. 
Breeds, M. 2004. Wild flowers of Braunton Burrows. Privately published.

Bruun, H.H. 2005. Rosa rugosa Thunb. Ex Murray. Journal of Ecology 93: 441-470.

Carboni, M., Santoro, R. \& Acosta, A. 2010. Susceptibility of dunes to alien invasion. Journal of Plant Ecology 3: 139-147.

Chyrtry, M., Maskell, L.C., Pino, J. \& Pysek, P. 2008. Habitat invasions by alien plants. Journal of Applied Ecology 45: 448-458.

Crawley, M.J. 1997. Aliens: the ecology of the non-indigenous flora of the British Isles. Oxford: Oxford University Press.

Crawley, M.J., Harvey, P.H. \& Purvis, A. 1996. Comparative ecology of the native and alien floras of the British Isles. Philosophical Transactions of the Royal Society of London B 351: 1251-1259.

Davy, A.J., Grootjans, A.P., Hiscock, K. \& Petersen, J. 2006. Development of ecohydrological guidelines for dune habitats - Phase 1. Peterborough: English Nature.

Edmondson, S.E. 2010a. Non-native plants on the Sefton Coast sand-dunes. In: Worsley, A.T., Lymbery, G., Holden V.J.C. \& Newton, M., eds. Sefton's dynamic coast, 201-213. Southport: Sefton Technical Services Department.

Edmondson, S.E. 2010b. Dune slacks on the Sefton Coast. In: Worsley, A.T., Lymbery, G., Holden V.J.C. \& Newton, M., eds. Sefton's dynamic coast, 178-187. Southport: Sefton Technical Services Department.

Edmondson, S.E., Gateley, P.S. \& Nissenbaum, D.A. 1988/89. National sand dune vegetation survey: the Sefton Coast. Report no. 917. Peterborough: Nature Conservancy Council.

Edmondson, S.E. \& Smith, P.H. 2005. Profile of aliens on a coastal sand dune system: case study of the Sefton Coast. In: Rotherham, I.D., ed, Loving the aliens??!!? Ecology, history, culture and management of exotic plants and animals: issues for nature conservation. Sheffield: Wildtrack Publishing.

English Nature 2005. Audit of non-native species in England. Research report no. 662. Peterborough: English Nature.

Fitzgerald, R.A. 2002. Clematis vitalba Traveller's-joy. In: Preston, C.D., Pearman, D.A. \& Dines, T.D., eds, New atlas of the British and Irish flora, 100. Oxford: Oxford University Press.

Gateley, P.S. \& Michell, P.E. 2004. Sand dune survey of the Sefton Coast. TEP, Warrington. Bootle: Sefton Metropolitan Borough Council.

Greenwood, E.F. 1999. Vascular plants: a game of chance. In: Greenwood, E.F., ed. Ecology and landscape development. A history of the Mersey Basin 195-211. Liverpool: Liverpool University Press.

Hall, B.R. \& Folland, C.J. 1967. Soils of the south-west Lancashire coastal plain. Harpenden: Agricultural Research Council.

Houston, J.A. 2008. Management of Natura 2000 habitats. 2190 humid dune slacks. Brussels: European Commission.

Houston, J.A., ed. 2011. Management case studies. In: Rooney, P.J., Houston, J.A. \& Weaver, G. The conservation and management of Sea Buckthorn (Hippophae rhamnoides) in the UK. Report of the workshop at Saltfleetby-Theddlethorpe and 
Gibraltar Point SAC, September 2009, 17-27. Sand Dune and Shingle Network occasional paper no. 3, Liverpool: Hope University Press.

Isermann, M. 2008. Expansion of Rosa rugosa and Hippophae rhamnoides in coastal grey dunes: effects at different spatial scales. Flora 203: 273-280.

Jones, M.L.M., Wallace, H.L., Norris, D., Brittain, S.A., Haria, S., Jones, R.E., Rhind, P.M., Reynolds, B.R. \& Emmett, B.A. 2004. Changes in vegetation and soil characteristics in coastal sand dunes along a gradient of atmospheric nitrogen deposition. Plant Biology 6: 598-605.

Marrs, R.H., Kirby, K.J., Le Duc, M.G., McAllister, H., Smart, S.M., Oksanen, J., Bunce, R.G.H. \& Corney, P.M. 2013. Native dominants in British woodland - a potential cause of reduced species-richness? New Journal of Botany 3: 156-168.

Maun, M.A. 2009. The biology of coastal sand dunes. Oxford: Oxford University Press. Millington, J.A., Booth, C.A., Fullen, M.A., Trueman, I.C. \& Worsley, A.T. 2010.

Distinguishing dune environments based on topsoil characteristics: a case study on the Sefton Coast. In: Worsley, A.T., Lymbery, G., Holden V.J.C. \& Newton, M., eds. Sefton's dynamic coast, 116-130. Southport: Sefton Technical Services Department.

Pearman, D. 2004. Invading aliens or invading natives? BSBI News 96: 41-42 https://archive.bsbi.org/BSBINews96.pdf

Pearman, D.A. 2007. 'Far from any house' - assessing the status of doubtfully native species in the flora of the British Isles. Watsonia 26: 271-290 http://archive.bsbi.org.uk/Wats26p271.pdf

Pearman, D. \& Walker, K. 2009. Comment: Alien plants in Britain - a real or imagined problem? British Wildlife, 21: 22-27.

Pearman, D., Bennallick, I \& Edwards, B. 2019. The impact of native and alien 'thugs' in semi-natural habitats. BSBI News 142: 6-11.

Preston, C.D., Pearman, D.A. \& Dines, T.D., eds. 2002. New atlas of the British and Irish flora. Oxford: Oxford University Press.

Rand, M. 2009. Letters: Alien plants in Britain - a real or imagined problem? British Wildlife 21: 150.

Ranwell, D., ed. 1972. The management of sea buckthorn Hippophae rhamnoides on selected sites in Great Britain. Report of the Hippophae study group. Norwich: The Nature Conservancy.

Richards, E.G. \& Burningham, H. 2011. Hippophae rhamnoides on a coastal dune system: a thorny issue? Journal of Coastal Conservation 15: 73-85.

Rodwell, J.S., ed. 2000. British plant communities volume 5. Maritime communities and vegetation of open habitats. Cambridge: Cambridge University Press.

Savidge, J.P., Heywood, V.H. \& Gordon, V., eds. 1963. Travis's flora of South

Lancashire. Liverpool: Liverpool Botanical Society.

Smith, P.H. 2006. An inventory of vascular plants for the Sefton Coast. BSBI News 102: 4-9 https://archive.bsbi.org/BSBINews102.pdf

Smith, P.H. 2009. The sands of time revisited. An introduction to the sand-dunes of the Sefton Coast. Stroud: Amberley Publishing. 
Smith, P.H. 2010. An inventory of vascular plants for the Sefton Coast. In: Worsley, A.T., Lymbery, G., Holden V.J.C. \& Newton, M. eds. Sefton's dynamic coast, 248250. Southport: Sefton Technical Services Department.

Smith, P.H. 2015. A revision of the inventory of vascular plants for the Sefton Coast, north Merseyside (v.c.59, South Lancashire), with particular reference to the 2014 Red List for England. BSBI News 129: 36-40.

Smith, P.H. 2017. Occurrence and ecology of Carex oederi (Small-fruited Yellow-sedge) on the Sefton Coast, Merseyside (v.c.59, South Lancashire). BSBI News 135: 2228.

Smith, P.H. 2019. Changing status of Blysmus compressus (Flat Sedge) in the Sefton Coast sand-dunes, north Merseyside, UK. British \& Irish Botany 1: 70-90. https://doi.org/10.33928/bib.2019.01.070

Smith, P.H. \& Deed, B. 2019. Japanese Rose (Rosa rugosa Thunb.): its invasion and colonisation of the Sefton Coast, north Merseyside, UK. British \& Irish Botany 1: 185-201. https://doi.org/10.33928/bib.2019.01.185

Smith, P.H. \& Kimpton, A. 2008. Effects of grey willow Salix cinerea removal on the floristic diversity of a wet dune-slack at Cabin Hill National Nature Reserve on the Sefton Coast, Merseyside, England. Conservation Evidence 5: 6-11.

Smith, P.H. \& Lockwood, P.A. 2016. Status of Juncus balticus (Baltic Rush) and its hybrids in England. BSBI News 131: 8-16.

Stace, C.A. 2019. New flora of the British Isles. $4^{\text {th }}$ ed. Middlewood Green, Suffolk: C \& M Floristics.

Stace, C.A. \& Crawley, M.J. 2015. Alien plants. The New Naturalist Library. London: Harper Collins.

Stefanowicz, A.M., Zubek, S., Stanek, M., Grześ, I.M., Rożej-Pabijan, E., Blaszkowski, J. \& Woch, M.W. 2019. Invasion of Rosa rugosa induced changes in soil nutrients and microbial communities of coastal sand dunes. Science of the Total Environment 677: 340-349.

Sturgess, P.W. 1993. Clear-felling dune plantations: studies in vegetation recovery on the Sefton Coast. In: Atkinson, D. \& Houston, J., eds. The sand dunes of the Sefton Coast, 85-89. Liverpool: National Museums \& Galleries on Merseyside.

Valcheva, M., Sopotlieva, D., Meshinev, T \& Apostolova, I. 2019. Is penetration of nonpsammophytes an underestimated threat to sand dunes? - a case study from western Pontic coast. Journal of Coastal Conservation 23:271-281.

Walmesley-Cotham, J. 1935. Forestry at Formby. Lecture to Liverpool Botanical Society, $5^{\text {th }}$ February 1935. Formby: Transcript, Formby Civic Society archive.

Weeda, E.J. 2010. The role of archaeophytes and neophytes in the Dutch coastal dunes. Journal of Coastal Conservation 14: 75-79.

Wheeler, D.J., Simpson, D.E. \& Houston, J.A. 1993. Dune use and management. In: Atkinson, D. \& Houston, J., eds. The sand dunes of the Sefton Coast, 129-149. Liverpool: National Museums \& Galleries on Merseyside.

Williamson, M. 1996. Biological invasions. London: Chapman \& Hall. 
Copyright retained by author(s). Published by BSBI under the terms of the Creative Commons Attribution 4.0 International Public License.

ISSN: $2632-4970$

https://doi.org/10.33928/bib.2020.02.102 